\title{
Ameliorative effect of ascorbic acid on rectal temperature and live weight of pigs transported by road for eight hours during the harmattan Season
}

\author{
${ }^{1 *}$ Adenkola, A.Y., ${ }^{2}$ Ayo, J.O, ${ }^{3}$ Sackey, A.K.B., ${ }^{4}$ Adelaiye, A.B. \\ $1^{1^{*}}$ Department of Physiology and Pharmacology, College of Veterinary Medicine, \\ University of Agriculture, Makurdi, Nigeria. \\ ${ }^{2}$ Department of Physiology and Pharmacology, Faculty of Veterinary Medicine, \\ Ahmadu Bello University, Zaria, Nigeria. \\ ${ }^{3}$ Department of Surgery and Medicine, Faculty of Veterinary Medicine, Ahmadu Bello \\ University Zaria, Nigeria. \\ ${ }^{4}$ Department of Human Physiology, Faculty of Medicine, Ahmadu Bello University \\ Zaria, Nigeria. \\ Corresponding Email: aadenkola@yahoo.com, Tel +2348054977696 \\ ABSTRACT
}

\begin{abstract}
Experiments were performed with the aim of investigating the effect of ascorbic acid (AA) on fluctuations in rectal temperature (RT) of pigs transported by road for eight hour during the harmattan season. Seventeen pigs administered with AA at the dose of $250 \mathrm{mg} / \mathrm{kg}$ orally and individually served as experimental animals, and 12 others administered orally with sterile water were used as control animals. Values of meteorological and RT parameters were recorded concurrently using standard procedures before the journey and at 30 min., 2, 4, 6 and $8 \mathrm{~h}$ of the journey, $3 \mathrm{~h}$ post-transportation and for three consecutive days post-transportation. The overall mean value of $38.62 \pm 0.12^{\circ} \mathrm{C}$ obtained in experimental pigs was significantly $(P<0.05)$ lower than $38.92 \pm 0.13^{\circ} \mathrm{C}$ recorded in control pigs. In conclusion, AA ameliorates the adverse effect of 8-h road transportation during harmattan season by decreasing the RT values in experimental pigs.
\end{abstract}

Keywords: Ascorbic acid, harmattan season, rectal temperature, pigs, road transportation.

\section{INTRODUCTION}

Pigs are reared for meat, and often they are transported several times in their lives (Warris, 2004; Vecerek et al., 2006, Adenkola, et al., 2009). The most common means of transportation for all livestock species including the pig all over the world and including Nigeria is by road (Ayo and Oladele, 1996; Adenkola and Ayo, 2009a; Adenkola et al., 2009), which is stressful (Von Borell, 2001; Minka and Ayo, 2007a, b; Adenkola et al., 2009). In several species of animals, especially in the pig the major cause of stress is the ambient temperature (Fayomi et al., 2003, Adenkola and Ayo, 2006) which may occur concurrently with high humidity during road transportation (Ferlazzo, 2003; Rajesh et al., 2003; Odore et al., 2004; Minka and Ayo, 2007a, b).

Environmental stress factors have been shown to cause oxidative stress and impair the activity of the antioxidant, vitamin C or ascorbic acid (AA) in vivo (Halliwell, 1996; Sahin et al., 2001). AA protects lipid peroxidation of cytomembranes (Akinwande and Adebule, 2003) and its supplementation has been demonstrated to provide beneficial effects against stress induced tissue damages in goats transported under tropical conditions (Ayo et al., 2006; Minka and Ayo, 2007a) and poultry (Ayo et al., 2007; Minka and Ayo, 2007b; Adenkola and Ayo, 2009b). The RT has been demonstrated to be of value in assessing changes induced by road transportation stress (Minka and Ayo, 2007a, b) and it serves as an index of stress in domestic animals (Mittal and Gosh, 1979; Adenkola and Ayo 2006, Adenkola and Ayo 2009b). Currently there is paucity of information on the adverse effects of road transportation in pigs, especially during the harmattan season, described to be the most stressful of all the three seasons (hotdry, rainy and harmattan) prevailing in the Northern Guinea Savannah zone of Nigeria (Igono et al., 1982). This zone is characterized by intensive livestock marketing and, consequently, transportation, especially during the harmattan season which coincides with the end of year festival activities. Information on the effect of AA on pigs transported by road during the harmattan season is also lacking in the available literature. 
The aim of the present study was to investigate the effect of AA on RT and body weight changes in pigs transported by road for 8-h during the harmattan season.

\section{MATERIALS AND METHODS}

Experimental Site: The experiment was performed during the harmattan season at the Livestock Pen Faculty of Veterinary Medicine, Ahmadu Bello University, Samaru-Zaria $\left(\begin{array}{cccc}11^{0} & 10^{\prime} \mathrm{N}, & 07^{0} & 38^{\prime} \mathrm{E}\end{array}\right)$, located in the Northern Guinea Savannah zone of Nigeria. The harmattan season occurs in the zone between late November and early March (Igono et al., 1982).

Experimental Animals and Management: Twenty nine local pigs, including males and non-pregnant, non-nursing females, with ages ranging from 9- 12 months were bought from different localities in Zaria environs two weeks before the experimental day. They were kept in a communal pen, made of concrete floor and iron walls with asbestos roofing. The pen measured $7.50 \mathrm{~m} \times 2.55 \mathrm{~m}$ with half the length of the wall to the roof without block work, which provided adequate ventilation. The pigs were not restrained inside the pen.

The pigs were pre-conditioned for two weeks before the commencement of the experiment. During the period, they were screened for haemoparasites and endoparasites by taking their blood and faecal samples for laboratory analyses. They were treated accordingly using oxytetracycline (Kepro B. $\mathrm{V}^{\circledR}$, Hollland) deep intramuscularly at the dose of 20 $\mathrm{mg} / \mathrm{kg}$ and thiabendazole (M.S.D AGVET ${ }^{\circledR}$, U.S.A.) at the dose of $25 \mathrm{mg} / \mathrm{kg}$ body weight.

Meteorological data:During the study period, the meteorological parameters of dry-bulb temperature (DBT) and relative humidity $(\mathrm{RH})$ were determined at the experimental site using dry- and wet-bulb thermometer (Brannan, England), and $\mathrm{RH}$ was calculated using the manufacturer's manual attached. The parameters were determined at 06:00, 13:00, and 18:00 $\mathrm{h}$ daily twice in a week for a total of six times before transportation, and also for three consecutive days post-transportation. Values of the meteorological parameters were also recorded at 30 minutes, 2, 4, 6, and $8 \mathrm{~h}$ of the journey and at $3 \mathrm{~h}$ post transportation and for three consecutive days after the journey.

Experimental Design:On each experimental day before loading the pigs into the vehicle, the experimental pigs $(n=16)$ were orally and individually administered with AA (Juhel ${ }^{\circledR}$ Nigeria Ltd, Enugu,
Nigeria) at $250 \mathrm{mg} / \mathrm{kg}$ (Chervyakov et al., 1977) dissolved in $20 \mathrm{ml}$ of water, while 13 pigs which served as control were each given $20 \mathrm{ml}$ of sterile water. Thereafter the RTs were taken together with the meteorological parameters at 06:00, 13:00 and 18:00 $\mathrm{h}$ for six times, twice in a week prior to transportation. On each day of transportation, the experimental animals were orally and individually administered AA (Juhel ${ }^{\circledR}$ Nigeria Ltd., Enugu, Nigeria) at $250 \mathrm{mg} / \mathrm{kg}$ dissolved in $20 \mathrm{ml}$ of water, while the control pigs were given $20 \mathrm{ml}$ of sterile water, orally and individually.

Food and water were withdrawn 12 hours before the journey and throughout the journey period, which lasted 8 hours. The vehicle travelled to Pambegua $\left(10^{\circ}\right.$ $4^{\prime} \mathrm{N}, 08^{0} 16^{\prime} \mathrm{E}$ ) along Zaria-Jos road from the Faculty of Veterinary Medicine, Ahmadu Bello University, Zaria $\left(11^{\circ} 10^{\prime} \mathrm{N}, 07^{\circ} 38^{\prime} \mathrm{E}\right)$ and back on tarred smooth and rough road covering a total distance of $260 \mathrm{~km}$ and at a speed range of $40-50 \mathrm{~km} / \mathrm{h}$. The journey duration included stop-overs, to measure RT, meteorological parameters and for police checking. After completing the journey, the pigs were unloaded at the spot where they were original loaded. The animals were fed and watered as they had been prior to the journey.

Vehicle design, loading, and journey time: A standard Ford six wheeler bus, popularly used to transport livestock was used to transport the pigs. The vehicle engine was in good condition, serviced and made ready for the journey. The floor of the vehicle was non-slippery and was covered with dry beddings before loading the animals. The inner compartment of the vehicle measured $3.22 \times 1.67 \times$ $1.2 \mathrm{~m}$ high. The sidewalls of the vehicle from the floor to the roof were smooth with no protrusion of sharp edge and with a window, which provide adequate ventilation. Each window measured $0.8 \times 0.44 \mathrm{~m}$ on both sides of the vehicle and was positioned, at the height of about $1.0 \mathrm{~m}$ from the floor. A door which measured $1.4 \times 1.2 \mathrm{~m}$ was provided at the rear end of the vehicle. Other transportation procedures were carried out in accordance with the standard guidelines governing the welfare of pigs during road transportation (Warris, 1998; Lambooij, 2000). Two persons loaded the pigs into the vehicle under relatively calm conditions. One person caught and carried a pig and led it to the other person, already inside the vehicle, who in turn placed the pig into the vehicle. The pigs were stocked at the density of 0.8 $\mathrm{m}^{2}$ per animal (Warris 1998). The journey commenced at 8:00 am 
Measurement of Physiological Parameters: The RT was measured using a standard clinical thermometer (Harman digital thermometer, Germany), inserted approximately $5-6 \mathrm{~cm}$ through the anus into the rectum of each pig (Zaytsev et al., 1971), and left until the alarm sounded, indicating the end of the reading. The pigs were caught easily and restrained lightly for measurements, which were completed within 15 minutes.

Weighing Procedure: The pigs were weighed using a conventional bathroom weighing scale (Philip Harris ${ }^{\circledR}$ Company, England). One person whose weight was recorded by the scale remained standing on it, while another person restrained and handed one pig to the person already standing on the weighing scale. The first reading on the scale was subtracted from the second reading to give the weight of each pig.

\section{RESULTS}

Meteorological Data: The meteorological data from the study period are shown in Table 1. The period was characterized by relatively low values of minimum AT of $19.0 \pm 3.1^{\circ} \mathrm{C}$ and low maximum AT of $23.3 \pm 0.7^{\circ} \mathrm{C}$. The DBT value obtained during the recordings was $19.3 \pm 2.7^{\circ} \mathrm{C}$. The harmattan season was characterized by relatively low humidity of 21.00 $\pm 0.51 \%$. The wind direction was North-east, and the speed was $226.43 \mathrm{~km} /$ day. The meteorological data during the post-transportation period (Table 2) were similar to those obtained during the pre-transportation period $(P>0.05)$ (Tables 1 and 2 ).

Table 1: Meteorological Data for the Study Period Pre-Transportation

\begin{tabular}{|c|c|c|c|c|c|}
\hline \multicolumn{5}{|c|}{ Ambient Temperature ( $\left.{ }^{0} \mathrm{C}\right)$} \\
\hline Hour & Minimum & Maximum & Dry-bulb & Relative Humidity (\%) & $\begin{array}{c}\text { Wind speed (km/ } \\
\text { day) }\end{array}$ \\
\hline $06: 00$ & 13 & 24 & 14 & 24 & 226.43 \\
\hline $13: 00$ & 23 & 24 & 23 & 20 & 226.43 \\
\hline 18: 00 & 21 & 22 & 21 & $21.00 \pm 0.51$ & \\
\hline Mean \pm S. E. M & $19.00 \pm 3.1$ & $23.33 \pm 0.7$ & $19.33 \pm 2.7$ & 2 & \\
\hline
\end{tabular}

Table 2: Post-Transportation Meteorological Data for the Study Period

\begin{tabular}{|l|c|c|c|c|c|}
\hline \multicolumn{5}{|c|}{ Ambient Temperature ( $\left.{ }^{\circ} \mathrm{C}\right)$} \\
\hline Hour & Minimum & Maximum & Dry-bulb & Relative Humidity (\%) & $\begin{array}{c}\text { Wind speed (km/ } \\
\text { day) }\end{array}$ \\
\hline $06: 00$ & 15 & 25 & 14 & 26 & 259.51 \\
\hline $13: 00$ & 24 & 26 & 24 & 20 & 259.51 \\
\hline $18: 00$ & 23 & 21 & 20 & $21.00 \pm 0.67$ & \\
\hline $\begin{array}{l}\text { Mean } \pm \text { S. } \\
\text { E. M }\end{array}$ & $20.67 \pm 2.85$ & $24.00 \pm 1.53$ & $19.33 \pm 2.91$ & & \\
\hline
\end{tabular}

Road Transportation of Pigs for eight hour: During the transportation the DBT value inside the vehicle before loading was $12^{0} \mathrm{C}$, while the value immediately after loading was $18^{0} \mathrm{C}$, Thereafter, the DBT rose gradually from $24^{\circ} \mathrm{C}$ in the first hour of the journey, and attained a peak value of $29^{\circ} \mathrm{C}$ in the second hour of the journey. The lowest DBT value of $21^{\circ} \mathrm{C}$ was recorded in the eighth hour of the journey (Table 3). The mean DBT inside the vehicle during the journey was $28.33 \pm 0.79^{\circ} \mathrm{C}$, whereas the $\mathrm{RH}$ ranged between $34-75 \%$ with a mean of $51.00 \pm$ $1.5 \%$.

Rectal Temperature during eight- hour Road Transportation of Pigs:The RT value obtained immediately after loading in experimental animals, $38.05 \pm 0.15^{\circ} \mathrm{C}$, was significantly lower than $(P<$ $0.05)$ the value of $38.63 \pm 0.23^{\circ} \mathrm{C}$ recorded in the control pigs (Figure 1). The RTs obtained during the journey fluctuated between $38.28 \pm 0.11^{\circ} \mathrm{C}$ and $38.95 \pm 0.07^{\circ} \mathrm{C}$ in the experimental pigs $(P<0.05)$, while those of the control pigs varied between 38.62 $\pm 0.08^{\circ} \mathrm{C}$ and $39.27 \pm 0.06^{\circ} \mathrm{C}(\mathrm{P}<0.05)$. The overall mean value of $38.62 \pm 0.12^{0} \mathrm{C}$ obtained in the experimental pigs was significantly $(P<0.05)$ lower than the corresponding value of $38.92 \pm 0.13^{0} \mathrm{C}$ recorded in the control pigs. The mean RT also fluctuated $(P<0.05)$ with the hours of the journey in the experimental and control pigs $(r=0.389,0.492$, respectively) (Table 4 ). 
Fluctuations in Rectal Temperature, Before Loading, Three Hours and Three Days Post-Transportation: Before loading the mean RT value of $37.30 \pm 0.18^{\circ} \mathrm{C}$ obtained in experimental pigs was not significantly different from that of $37.87 \pm 0.26^{\circ} \mathrm{C}$ recorded in the control animals. RT values obtained pre-loading did not differ $(P>0.05)$ when compared with corresponding values recorded $3 \mathrm{~h}$ posttransportation in experimental and control pigs (Table 5). The mean RT recorded within three hours of arrival from the journey in the control pigs was 38.28 $\pm 0.13^{0} \mathrm{C}$, and the value was significantly $(P<0.05)$ higher than the corresponding value of $37.98 \pm 0.15^{\circ}$ $\mathrm{C}$ recorded in the experimental pigs. There was no significant difference $(P>0.05)$ between the recorded RT value in the experimental and control pigs three days after transportation (Table 6).

Table 3: Ambient Temperature and Relative Humidity inside the Vehicle during Long-Term Road Transportation

\begin{tabular}{|c|c|c|}
\hline Hour of Journey & Dry-Bulb ( $\left.{ }^{\mathbf{0}} \mathbf{C}\right)$ & $\begin{array}{c}\text { Relative } \\
\text { Humidity (\%) }\end{array}$ \\
\hline 30 min & 24 & 75 \\
\hline 2 & 29 & 63 \\
\hline 4 & 27 & 63 \\
\hline 6 & 28 & 63 \\
\hline 8 & 21 & 34 \\
\hline Overall Mean \pm SEM & $28.33 \pm 0.79$ & $51.00 \pm 1.50$ \\
\hline
\end{tabular}

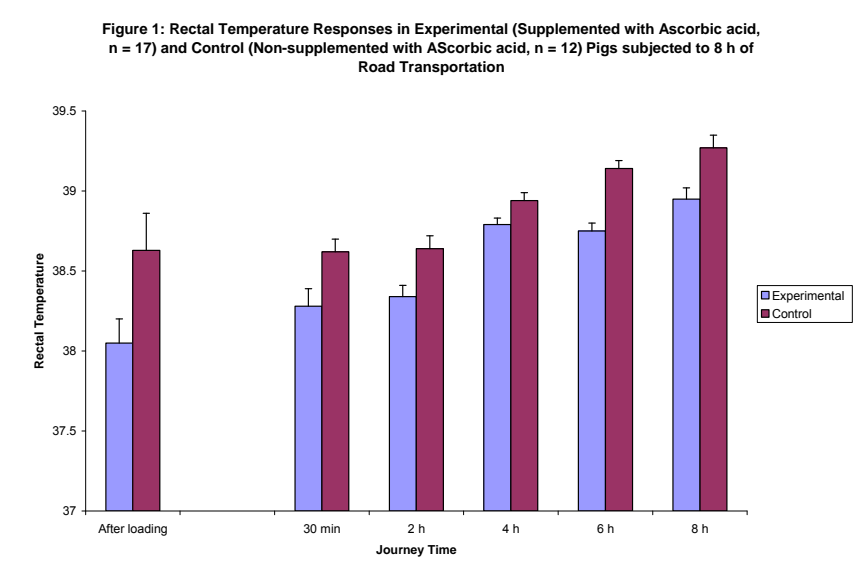

Table 4: Relationships between Hour of the Journey, Dry-bulb Temperature, Relative Humidity, Rectal Temperature, during Long-term Road Transportation of Pigs.

\begin{tabular}{|l|c|c|}
\hline \multicolumn{1}{|c|}{ Hour of Day } & \multicolumn{2}{|c|}{$\begin{array}{c}\text { Experimental }(\mathbf{n}=16) \\
\text { Control } \\
(\mathbf{n}=\mathbf{1 3})\end{array}$} \\
\hline $\begin{array}{l}\text { Hour of Journey and Rectal } \\
\text { Temperature }\end{array}$ & 0.389 & 0.492 \\
\hline $\begin{array}{l}\text { Dry-bulb Temperature and } \\
\text { Rectal Temperature }\end{array}$ & -0.357 & -0.401 \\
\hline $\begin{array}{l}\text { Relative-Humidity and } \\
\text { Rectal Temperature }\end{array}$ & -0.574 & -0.497 \\
\hline $\begin{array}{l}\text { Maximum Temperature } \\
\text { and Rectal Temperature }\end{array}$ & -0.614 & -0.632 \\
\hline $\begin{array}{l}\text { Minimum Temperature and } \\
\text { Rectal Temperature }\end{array}$ & -0.740 & -0.359 \\
\hline
\end{tabular}

Body weight: There was no statistically $(P>0.05)$ significant difference between the live weights recorded in the pigs' pre-transportation and posttransportation; however, a percentage difference of 5.78 and 20.05 was obtained in the experimental and control pigs, respectively (Table 7 )

Table 5: Dynamics of Rectal Temperature Responses in Experimental (supplemented with Ascorbic Acid, $n=17$ ) and Control (Non-supplemented with Ascorbic Acid, $n=13$ ) Pigs before and after Long-term Road Transportation (Mean \pm SEM)

\begin{tabular}{|c|c|c|c|c|c|c|c|c|}
\hline \multirow{2}{*}{ Period } & \multicolumn{2}{|c|}{ Mean \pm SEM } & \multicolumn{2}{|c|}{ Maximum } & \multicolumn{2}{|c|}{ Minimum } & \multicolumn{2}{|c|}{ Range } \\
\hline & Experimental & Control & $\begin{array}{l}\text { Experi } \\
\text { mental }\end{array}$ & Control & $\begin{array}{l}\text { Experi } \\
\text { mental }\end{array}$ & Control & $\begin{array}{l}\text { Experi } \\
\text { mental }\end{array}$ & Control \\
\hline 3 h Post-Transportation & $37.98 \pm 0.15$ & $38.28 \pm 0.13$ & 38.8 & 38.8 & 36.5 & 37.7 & 2.3 & 1.1 \\
\hline $\begin{array}{l}\% \text { Rectal Temperature } \\
\text { Change }\end{array}$ & 1.8 & 1.1 & 0.0 & -7.7 & 0.3 & 3.2 & -4.4 & -1.4 \\
\hline
\end{tabular}


Table 6: Rectal Temperature of Experimental (supplemented with Ascorbic Acid, $n=17$ ) and Control (Nonsupplemented with Ascorbic Acid, $n=12$ ) Pigs Three Days after Long-term Road Transportation.

\begin{tabular}{|c|c|c|c|c|c|c|c|c|}
\hline \multirow[t]{2}{*}{ Hour } & \multicolumn{2}{|l|}{ Mean \pm SEM } & \multicolumn{2}{|l|}{ Maximum } & \multicolumn{2}{|l|}{ Minimum } & \multicolumn{2}{|l|}{ Range } \\
\hline & Experimental & Control & $\begin{array}{l}\text { Experim } \\
\text { ental }\end{array}$ & Control & $\begin{array}{l}\text { Experimen } \\
\text { tal }\end{array}$ & Control & $\begin{array}{l}\text { Experimen } \\
\text { tal }\end{array}$ & Control \\
\hline 06:00 & $38.08 \pm 0.15$ & $37.79 \pm 0.14$ & 39.4 & 39.5 & 36.7 & 37.2 & 2.7 & 2.3 \\
\hline $13: 00$ & $38.74 \pm 0.11$ & $39.30 \pm 0.14$ & 39.7 & 40.0 & 38.0 & 37.8 & 1.7 & 2.2 \\
\hline $18: 00$ & $38.80 \pm 0.09$ & $39.05 \pm 0.13$ & 40.2 & 40.2 & 38.2 & 38.5 & 2.0 & 1.7 \\
\hline $\begin{array}{ll}\text { Overall Mean } \\
\pm \text { SEM }\end{array}$ & $38.54 \pm 0.32^{\mathrm{NS}}$ & $\begin{array}{ll}38.71 & \pm \\
0.44^{\text {NS }} & \\
\end{array}$ & $\begin{array}{l}39.77 \text { I } \\
0.31^{\mathrm{NS}}\end{array}$ & $\begin{array}{l}39.90 \pm \\
0.30^{\mathrm{NS}} \\
\end{array}$ & $\begin{array}{l}37.63 \pm \\
0.45\end{array}$ & $\begin{array}{ll}37.83 & \pm \\
0.40^{\mathrm{NS}} & \end{array}$ & $\begin{array}{ll}2.13 & \pm \\
0.36^{\mathrm{NS}} & \\
\end{array}$ & $\begin{array}{l}2.06 \\
0.28^{\mathrm{NS}} \\
\end{array}$ \\
\hline
\end{tabular}

Table 7: Effects of ascorbic acid on live weights on pigs transported for four hours

\begin{tabular}{|l|l|l|l|l|}
\hline \multicolumn{3}{|c|}{ Live weight, kg (Mean \pm SEM) } \\
\hline Animals & $\mathrm{n}$ & Pre-transportation & Post-transportation & $\begin{array}{l}\text { Percent live weight difference between } \\
\text { and pre and post-transportation live } \\
\text { weights }\end{array}$ \\
\hline Experimental pigs & 17 & $24.41 \pm 2.93$ & $23.00 \pm 2.79$ & -5.78 \\
\hline Control pigs & 12 & $29.92 \pm 3.30$ & $23.92 \pm 3.02$ & -20.05 \\
\hline
\end{tabular}

\section{DISCUSSION}

The current UK legislation [Welfare of Animals (Transport) Order, 1997] states that pigs can be transported for a maximum of eight hours after which they must be unloaded, fed, watered and rested for 24 hours before any further journey (Brown et al., 1999). This justifies the reason for transporting the pigs for 8-h duration.

From the study period the meteorological data recorded during the 8-h journey were similar to the previous findings that harmattan season was thermally stressful to livestock (Igono et al., 1982; Ayo et al., 1998a and b) in goats and in piglet (Adenkola and Ayo, 2006). The RT values recorded in both the treated and control pigs fell within the established normal range of $38-40^{\circ} \mathrm{C}$ for the pigs (Zaytsev et al., 1971). This indicated that the pigs were healthy and fit for the journey. Immediately after loading and just before the commencement of the journey, the values of RT in both experimental and control pigs increased significantly $(P<0.05)$. Such an increase indicated that the loading of the pigs into the vehicle was stressful and that it altered sharply the RT of the pigs. Highest physiological and biochemical responses have been shown to occur during handling and loading by Kannan et al. (2000) and Minka and Ayo (2007) in the goat. Perez et al. (2002), Maria et al. (2004) and Minka and Ayo $(2007 a, b)$ reported that loading was more stressful than unloading. It should be noted that during the loading exercise, the differences in the RT values in both the treated (administered with $A A$ ) and control pigs (administered with sterile water only) were not significant $(P>0.05)$. This observation agreed with the result obtained by previous workers who showed that $A A$ administration to pigs did not exert any significant effect on the RT during loading in goats (Minka, 2005) and in chicken Ajakaiye, (2006). This could be due to the fact that more time was needed for the effect of the vitamin to be manifested following their administration since it was given shortly before loading. Further studies may be required to elucidate the effect of AA on loading exercise, which is an important component of transportation as observed by Speer et al. (2001) and Tarrant and Grandin (2000), who also characterized the transport process as beginning with the assembly and including loading. The RT values recorded during the journey demonstrated clearly that transportation increased significantly the values of RT in both the experimental and control groups of transported pigs. This confirmed the findings of Ayo and Oladele (1996), Rajion et al. (2001) that the period of transportation of an animal is one of the most traumatic in its life time (Crowther et al., 2003; Vecerek et al., 2006).

The result showed clearly that $A A$ reduced the increased RT values in pigs, and hence the adverse effects of road transportation stress. Although, the mechanism of action of AA on the body temperature was not investigated in the present study, it is apparently, due to the scavenging action of $A A$ on free radicals produced in the body during stress. AA has an ability to stabilize the membrane integrity of the cells and therefore, decreases membrane susceptibility to lipid peroxidation by acting as an electron carrier. It can also give up two electrons and 
thus, be converted to dehydro-L-ascorbic acid (Whitehead and Keller, 2003) or donate free molecule of hydrogen (Koshebekov, 1991: Altan et al., 2003). The present result also indicated that the RT values rose significantly with the duration of the journey, especially in the control pigs. This supported the findings of Vecerek et al. (2006) that the road transportation stress burden of pigs increases with the increasing transport distance. This further demonstrated that road transportation was more stressful to control than experimental pigs, administered with AA. The meteorological results obtained demonstrated that transportation of pigs during the thermally stressful harmattan may adversely affect the pigs, and, consequently, impair the homeostatic mechanisms of the animals. This is similar to the findings of Vecerek et al. (2006) that the AT during road transportation influences the level of well-being in pigs. Such responses have been established to have negative effects on both the health status and productivity of animals (West, 2003). Besides, environment stress factors have been shown to cause oxidative stress and impair antioxidant, AA in vivo (Sahin et al., 2001). Thus, AA supplementation attenuates the negative responses of pigs to transportation stress. The fact that the correlation coefficients between the DBT, $\mathrm{RH}$ and the RT were higher in the control than the experimental pigs during transportation strongly suggested that $A A$ was involved in the reduction of the stressful effects of meteorological conditions prevailing during the harmattan season on the experimental pigs. The results further showed the beneficial effects of AA on the adverse effects of the unfavourable meteorological conditions prevailing during the stressful harmattan season. The result of present study has shown for the first time that AA reduced $R T$ values and the adverse effects of meteorological conditions and therefore, may ameliorate the adverse effects of long distant road transportation. This is important because pigs are often transported to areas located far outside where they are produced for many economic purposes as reported by Giovagnoli et al. (2002). A colossal loss both in quantity and quality of meat, high morbidity and mortality has been observed in transported animals (Ayo et al., 1996; Speer et al. 2001; Vecerek et al., 2006). Thus, the administration of $A A$ to pigs over a long distance and across different geographical zones for many hours may result in minimal loss in pigs if they are administered with AA prior to commencement of the journey.
The values of RT obtained in the transported pigs for three days after the journey were not significantly different from those obtained three days before transportation of the pigs. This finding showed that the increase in RT values recorded during the 8-h journey period was transient; and at the end of the third day, the values were restored to pretransportation level. The results demonstrated that 8$h$ road transportation of pigs during the harmattan season may not have adverse effects on RT and, consequently, health and productivity of pigs, especially if the pigs are administered with AA prior to the commencement of the journey. Such transient effect of road transportation stress on the pigs, confirmed the findings of Adenkola and Ayo (2006) that pigs reared in the Northern Guinea Savannah Zone of Nigeria have established relatively stable thermoregulatory mechanisms capable of combating adverse effects of environment stress factors prevailing in the zone. The results of the present study showed fluctuations in the values of RT as previously describe as characteristics of most mammals (Piccione and Caola, 2002). The results were consistent with the findings of Ayo et al. (2007) in pullets and Adenkola and Ayo (2009b) in turkeys, and Minka and Ayo (2007b) in goats. They also supported the findings of Makarov (1989) and Piccione and Caola (2002) that such a diurnal fluctuation is driven by a biological clock, classical of most mammals.

Unlike in control pigs, the liveweight of pigs treated with AA did not alter significantly after the journey. This indicated that $A A$, apparently decreased the negative effects of transportation on the pigs. This finding agrees with those of Knowles et al. (1999a) and Brown et al. (1999), who demonstrated that road transportation, resulted in decrease in liveweight of animals. The fact that liveweight of transported pigs administered with AA did not reduce significantly after the journey showed that losses due to liveweight often encountered during transportation of pigs, may be reduced or completely eliminated by $A A$ administration; thereby enhancing the profitability and productivity of the pigs in the zone. The proximate cause of loss in liveweight during transportation has been described to be associated with dehydration of the tissues as a result of intensification of energy degradation of carbohydrate and fat (Knowles et al., 1999b).

\section{CONCLUSION}

Harmattan season is stressful to livestock and transporting pigs during this period imposes 
additional stress. The administration of AA prior to transportation ameliorates the adverse effects of road transportation stress during the harmattan season.

\section{REFERENCES}

Adenkola, A. Y. and Ayo, J. O. (2006). Effect of ascorbic acid on diurnal variations in rectal temperature of piglets during the harmattan season. Proc. $11^{\text {th }}$ Ann.Conf. Anim. Sci. Assoc. Nig. 11: $9-12$

Adenkola, A. Y. and Ayo, J. O. (2009a). Effect of road transportation on erythrocyte osmotic fragility of pigs administered ascorbic acid during the harmattan season in Zaria, Nigeria. J. Cell Anim. Biol. 3(1): 004008.

Adenkola, A. Y. and Ayo. J. O. ( 2009b). Effect of Ascorbic Acid on Rectal Temperature Fluctuations in Indigenous Turkeys during the Hot-Dry Season. Int. J. Poul. Sci. 8(5): $457-461$.

Adenkola, A.Y., Ayo, J. O., Sackey, A. K. B., Adelaiye, A. B. and Minka, N. S (2009a). Excitability scores of pigs administered ascorbic acid and transported during the harmattan season. Vet. Arhc, 79 (5), 471-480.

Ajakaiye, J. J. (2006). Effects of Vitamin C and E on some physiological parameters of Shika brown layer chickens transported by road during the hot-dry season. M. Sc. Thesis. Department of Physiology and Pharmacology. Ahmadu Bello University Zaria.

Akinwande, A. I. and Adebule, A. O. A. (2003). Ascorbic acid and beta-carotene alleviate oxidative effect of London Kingsize ${ }^{\circledR}$ cigarette smoke on tissue lipids. Nig. J. HIth. Biochem. Sci.. 2(1): 12 - 15.

Altan, O., Pabuccuoglu, A., Konyalioglu, S.and Bayracktar, H. (2003). Effect of heat stress on oxidative stress, lipid peroxidation and some stress parameters in broilers. Brit. Poul. Sci.. 44 (4): 54 - 55

Ayo, J. O. and Oladele, S. B. (1996). Road transport stress in food animals in Nigeria. A review. Nig.Vet. J. (Special Edition). 1(1): $49-57$.

Ayo, J. O., Oladele, S. B. Fayomi,, A., Jumbo, S. D and Hambolu, J. O. (1998a.) Body temperature, respiration and heart rate in the Red Sokoto goat during the harmattan season. Bull. Anim. Produc. Afric.. 46: 161166.

Ayo, J. O, Oladele, S. B.,. Ngam, S., Fayomi, A. and Afolayan, S. B. (1998b). Diurnal fluctuations in rectal temperature of the Red Sokoto goat during the harmattan season. Res. Vet. Sci. 66: 7 - 9.

Ayo, J. O.,. Owoyele, O. O., Dzenda, T. (2007). Effect of ascorbic acid on diurnal variations in rectal temperature of Bovan Nera pullets during the harmattan season. Int. J.Poult. Sci. 6(8): 612 - 616

Ayo, J. O., Minka, N. S and Mamman, M. (2006) Excitability scores in goats administered ascorbic acid and transported during hot-dry conditions. J. Vet. Sci.. 7: $127-131$

Brown, S. N., Knowles, T. G., Edward, J. E. and Warris. P. D. (1999). Behavioural and physiological responses of pigs to being transported for up to 24 hours followed by six hours recovery in lairage. The Vet. Rec. 145: 421 426.

Chervyakov, D. K., Yevdokimov, P. D. and Vishker. A. S. (1977). Drugs in Veterinary Medicine. Kolos Publishing House, Moscow, 496pp (in Russian).

Crowther, C., Davies, R. and Glass, W. (2003). The effect of night transportation on the heart and skin temperature of ostriches during real transportation. Meat Sci. 64: 365 - 370

FAOSTAT. (2002). FAO statistical databases (http://apps.fao.org); Food and Agriculture Organisation of the United Nations.

Fayomi, A., Ayo, J. O. and Olaniyan, O. (2003). Diurnal variations in rectal temperature of the West African Dwarf goat during the harmattan season. Proc. $28^{\text {th }}$ Ann. Conf. Nig.Soc. Anim. Prod. 28: 34 - 36.

Ferlazoo, A. (2003). Large animal transportation procedures in Europe: Present and future. Vet. Res. Comm. 1: 513 - 514

Giovagnoli, G., Marinucci, M. T., Bolla, A. and Borghese. A. (2002). Transport stress in horses: An electromyographic study on balance preservation. Livestock Production Science.73: 247 - 254.

Halliwell, B. (1996). Vitamin C. An antioxidant or pro oxidant in vivo. Free Rad. Res. 25: 439 - 454.

Igono, M. O. Molokwu, ., E. C. I and Aliu, Y. O. (1982). Body temperature responses of Savanna Brown goat to the harmattan and hot-dry season. Int. J. Biometeorol. 26: $225-230$.

Kannan, G., Terrill, T. H. Konakou, B. Gazal, O. Gelaye, S., Amoah, E. A. and Samake, S. (2000). Transportation of goats: Effects on physiological stress responses and live weights loss. J. Anim. Sci.. 78: 1450 - 1457.

Knowles, T. G., Warris, P. D., Brown, S. N. and Edwards, J. E. (1999). Effects on cattle of transportation by road for up to 31 hours. The Vet. Rec. 145: 575- 582.

Koshebekov, Z. K. (1991). Energy and mineral element metabolism. In: Golikov A H (ed.). Physiology of Domestic Animals. Agropromizdat, Moscow, Pp. 115157 (in Russian).

Lambooij, E. (2000). Transport of pigs. In: Livestock Handling and Transport. $T$ Gradin (ed.). $C A B I$ Publishing, New York. Pp 275 - 296.

Makarov, V. I. (1989). Changes in biorhythms in extremal conditions. In: Chronobiology and Chronomedicine. 
Meditsina Publishing House, Moscow, Pp 169 - 183 (in Russian).

Maria, G. A., Villaroel, M., Chacon, G. and Gebresenbet, G. (2004). Scoring system for evaluating the stress to cattle of commercial loading and unloading. The Vet. Rec. 154(26): 818 - 821.

Minka, N. S. (2005). Effects of ascorbic acid on some physiological parameters of Red Sokoto goats transported by road during the hot-dry season. M. Sc. Thesis. Department of Physiology and Pharmacology. Ahmadu Bello University Zaria.

Minka, N. S. and Ayo, J. O. (2007a). Road transportation effect on rectal temperature, respiration and heart rates of ostritch (Struthio camelus) chick. Vet. Arhiv,77(1), 3946.

Minka, N. S. and Ayo, J. O. (2007b). Physiological responses of transported goats treated with ascorbic acid during the hot-dry season. Anim. Sci. J. 78: 164172

Mittal, J. P. and Ghosh, P. K. (1979). Body temperature, respiration and pulse rate in Corriedale, Marwari and Magra sheep in the Rajasthan desert. J. Agric. Sci. (Cambridge). 93: 589 - 591.

Odore, R., Angelo, A. D., Badino, P. Bellino, C., Pagliasso, S. Re. G. (2004). Road transportation affects blood hormone levels and lymphocyte glucocoticoid and ßadrenergic receptors concentration in calves. The Vet. J. 168: $297-303$

Perez, M. P., Palacio, J., Santolaria, M. P. Acena, M. C., Chacon, G.. Gascon, M.. Calvo, J. H. Zaragoza, P., Beltran, J. A., Gracia-Belenguer, S. (20020. Effect of transport time on welfare and meat quality in pigs. Meat Sc. $61,425-433$.

Piccione, G. and Caola, G. (2002). Biological rhythm in livestock. J. Vet. Sci. 3: $145-157$.

Rajesh, B Maralidharan,., M. R., Ramesh, V., Arunachalam, S., Sivakumar, T. (2003). Effects of transport stress on blood profile in sheep. Ind. Vet. J. $80,511-514$.
Rajion, M. A., S. Mohammed, L. Zukifti, Y. M Goh. 2001. The effect of road transportation on some physiological stress measures in goats. Asian-Austral. J. Anim. Sci. 9: $1250-1262$.

Sahin, K., Sahin, N., Onderci, M. Yaraliogu, S. Kucuk, O. (20010. Protective role of supplemental vitamin $E$ on lipid peroxidation, vitamins $E, A$ and some mineral concentrations of broilers reared under heat stress. Vet. Med.(Czechslosvakia). 46, 140-144.

Speer, N. C., Slack, G. and Troyer, E. (2001). Economic factors with livestock transportation. J. Anim. Sci. 79(E. Suppl.): 166- E170

Tarrant, V. and Grandin, T. (2000). Cattle transport. In: T. Grandin, T., (ed.). Livestock Handling and Transport. CABI Publishing, New York, Pp. 151-173

Vecerek, V., Malena, M., Malena Jr, M., Voslarova, E. and Chloupek, P. (2006). The impact of transport distance and season on losses of fattened pigs during trasnsport to the slaughter house in the Czech Republic in the period from 1987 to 2004. Vet. Med. 51(1): $21-28$.

VonBorell, E. H. (2001). The biology of stress and its application to livestock housing and transportation assessment. J. Anim. Sci. 79(E. suppl.): $260-267$.

Warriss, P. D. (1998b). Choosing appropriate space allowance for slaughter pigs transported by road: a review. The Vet. Rec. 142: 449 - 454.

Warriss, P. D. (2004). The transport of animals: A long way to go. The Vet. J. 168: $213-214$.

West, J. W. (2003). Effects of heat stress on production in dairy cattle. Amer. Dairy Sci. Assoc.. 86: 2131 - 2144

Whitehead, C. C., Keller, T. (2003). An update on ascorbic acid in poultry (Reviews). World's Poult. Sci. Assoc. 59: $161-184$.

Zaytsev, V. I., Sinev, A. B., Ionov, P. S., Vasileyev, A. V. , Sharabrin, I. G. (1971). Clinical Diagnosis of Internal Diseases of Farm Animals. Kolos Publishing House, Moscow, 336pp (in Russian). 